\title{
INCREASE OF COMPETITIVENESS OF THE ENTERPRISE BY ELECTRONIC BUSINESS TECHNOLOGIES
}

\author{
PhD in Economics, Assistant Professor Nataliya Demchenko, \\ PhD in Economics, Assistant Professor Diana Zoidze \\ Ukraine, Kharkiv, National University of Pharmacy, Management and Administration Department
}

DOI: https://doi.org/10.31435/rsglobal_ijite/31012019/6332

\section{ARTICLE INFO \\ Received 19 November 2018 \\ Accepted 11 January 2019 \\ Published 31 January 2019 \\ KEYWORDS \\ competitiveness, electronic business (e-business), \\ information and communications technologies, enterprise information system (EIS), enterprise management system, management of e- business, contractual work automation.} \begin{abstract}
The article deals with global trends in e-commerce, especially conducting e-commerce in Ukraine. The article also explores the positive and negative factors affecting the development of e-commerce enterprises in Ukraine. Particular attention is paid to the consideration of the stages of development of e-commerce in the enterprise, issues of enterprise management in terms of focusing on e-business in the modern conditions of informatization and globalization.
\end{abstract}

Citation: Nataliya Demchenko, Diana Zoidze. (2019) Increase of Competitiveness of the Enterprise by Electronic Business Technologies. International Journal of Innovative Technologies in Economy. 1(21). doi: 10.31435/rsglobal_ijite/31012019/6332

Copyright: (C) 2019 Nataliya Demchenko, Diana Zoidze. This is an open-access article distributed under the terms of the Creative Commons Attribution License (CC BY). The use, distribution or reproduction in other forums is permitted, provided the original author(s) or licensor are credited and that the original publication in this journal is cited, in accordance with accepted academic practice. No use, distribution or reproduction is permitted which does not comply with these terms.

Introduction. The scope of e-business is developing dynamically around the world. The instantaneous rate of transfer of information, the absence of geographical and time constraints for consumers, low costs, a wide range of unique marketing tools and other benefits determine the interest to e-business by enterprises, manufacturers of goods and services. E-commerce (e-commerce) is a form of business transactions in which the interaction of the parties is carried out electronically instead of physical exchange or direct physical contact and as a result of which the right of ownership or use of a product or service is transferred from one person to another. E-commerce (from eng. e-commerce) is a sector of the economy, which includes all financial and trade transactions carried out using computer networks, and business processes associated with conducting such transactions [15]. E-commerce includes: Electronic Information Interchange (Electronis Data Interchange, EDI), Electronic capital flow (Electronic Funds Transfer, EFS), Electronic commerce (e-trade), Electronic money (e-cash), Emarketing (e-marketing), Electronic banking (e-banking), Electronic insurance services (e-insurance).

Literature Review. Issues of the use of information systems and technologies in business and on the development of e-business have been considered by such scientists: A. Baranov, A. Bereza, V. Bykov, D. Eimor, B. Gates, A. Gerashchenko, M. Dell, M. Castells, N. Medzhibovskaya, G. Mins, S. Parinov, V. Pleskach, K. Peitel, A. Pushkar, D. Siegel and others. 
The purpose of the article is to study the development and priority areas of Internet commerce in Ukraine under the influence of global trends in e-commerce.

Research results. The global e-commerce market is one of the most dynamic and steadily growing markets. According to the report eMarketer [1], in 2017, the global retail Internet trade will reach $10.1 \%$ of retail sales in general, in 2021 , this share will increase to $16,1 \%$; the growth rate of ecommerce will outstrip the growth of retail sales in general (Fig. 1).

Technologically developed countries consider e-business a powerful mechanism for economic development and expansion of sales markets for goods and services. Therefore, the development of ebusiness is strongly supported and stimulated by government regulatory funds. The volume of modern global e-commerce is estimated at several trillions of dollars, but analysts predict its further growth to 10 trillion dollars in the coming years. The largest is the e-commerce market in the US and Europe (EU countries).

The European e-commerce market, which represents European countries - Austria, Belgium, Denmark, Finland, France, Germany, Greece, Ireland, Italy, Luxembourg, the Netherlands, Norway, Portugal, Spain, Sweden, Switzerland and the United Kingdom - are projected experts will increase the rate of growth annually by $10-15 \%$ over the next 5 years.

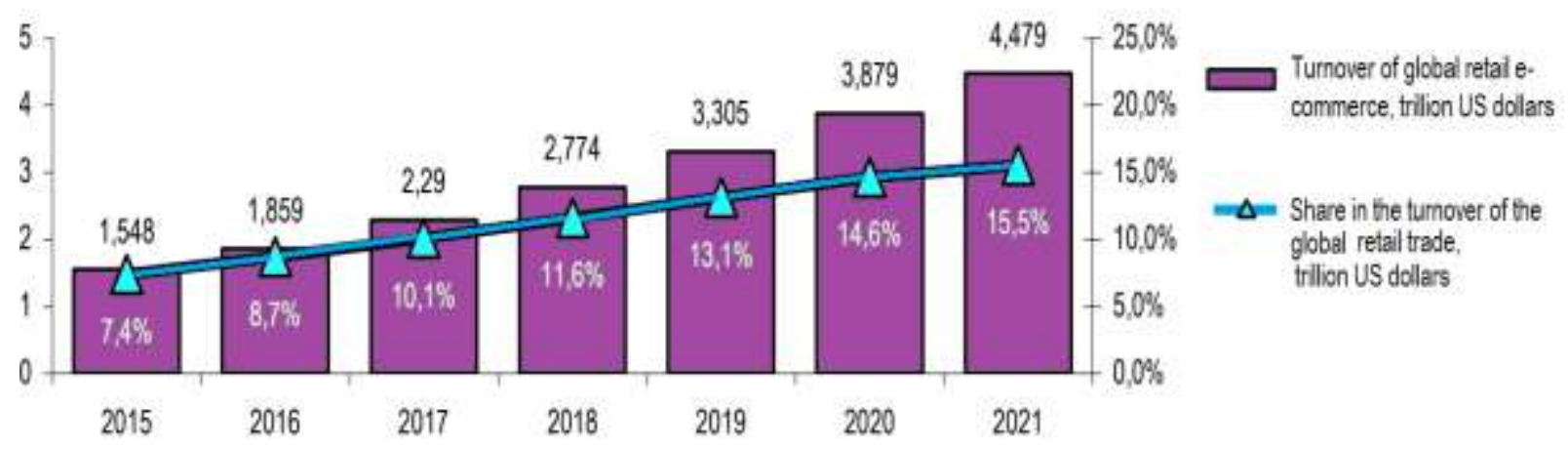

Fig. 1 - Dynamics of the volume of world e-commerce [2]

Worldwide e-commerce is represented in the following segments: direct sales of goods and services, information placement, corporate purchases. Moreover, the largest share belongs to the first segment and is about $80 \%$. Most experts point out that the Ukrainian e-business and commerce market is quite promising.

The spread of e-business in Ukraine is promoted by the growing number of Internet users (about 50\% of the population), the introduction of electronic payment systems for goods and services, the development of the national ICT market and other signs of informatization of society.

The analysis of the share of e-commerce in the volume of GDP of Ukraine and Western European countries for 2009-2017 is presented in Fig. 2.

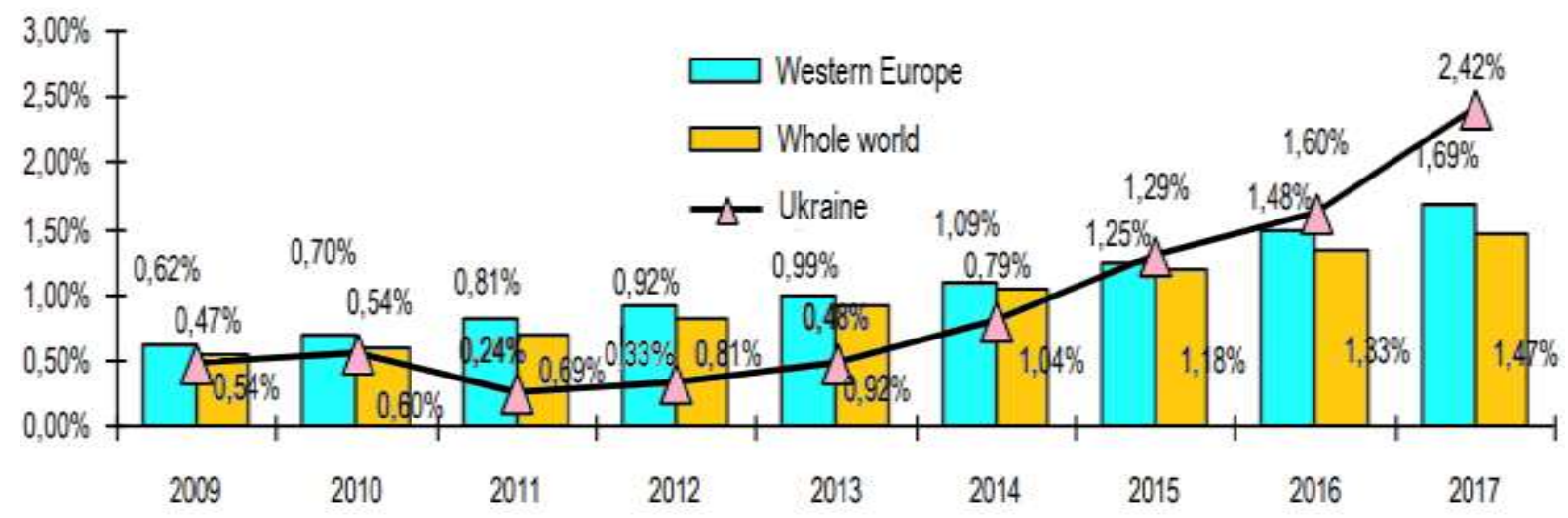

Fig. 2. Dynamics of the share of e-commerce in GDP of Ukraine, the world and Western Europe in 2009-2017. [2] 
The development of e-commerce relies on attracting more and more users to the Internet (Fig.)

The dynamics of indicators of the development of electronic commerce in Ukraine, calculated by the authors, taking into account differences in the methods of evaluation and fluctuations in the hryvnia exchange rate to major world currencies, is given in Table. 1.

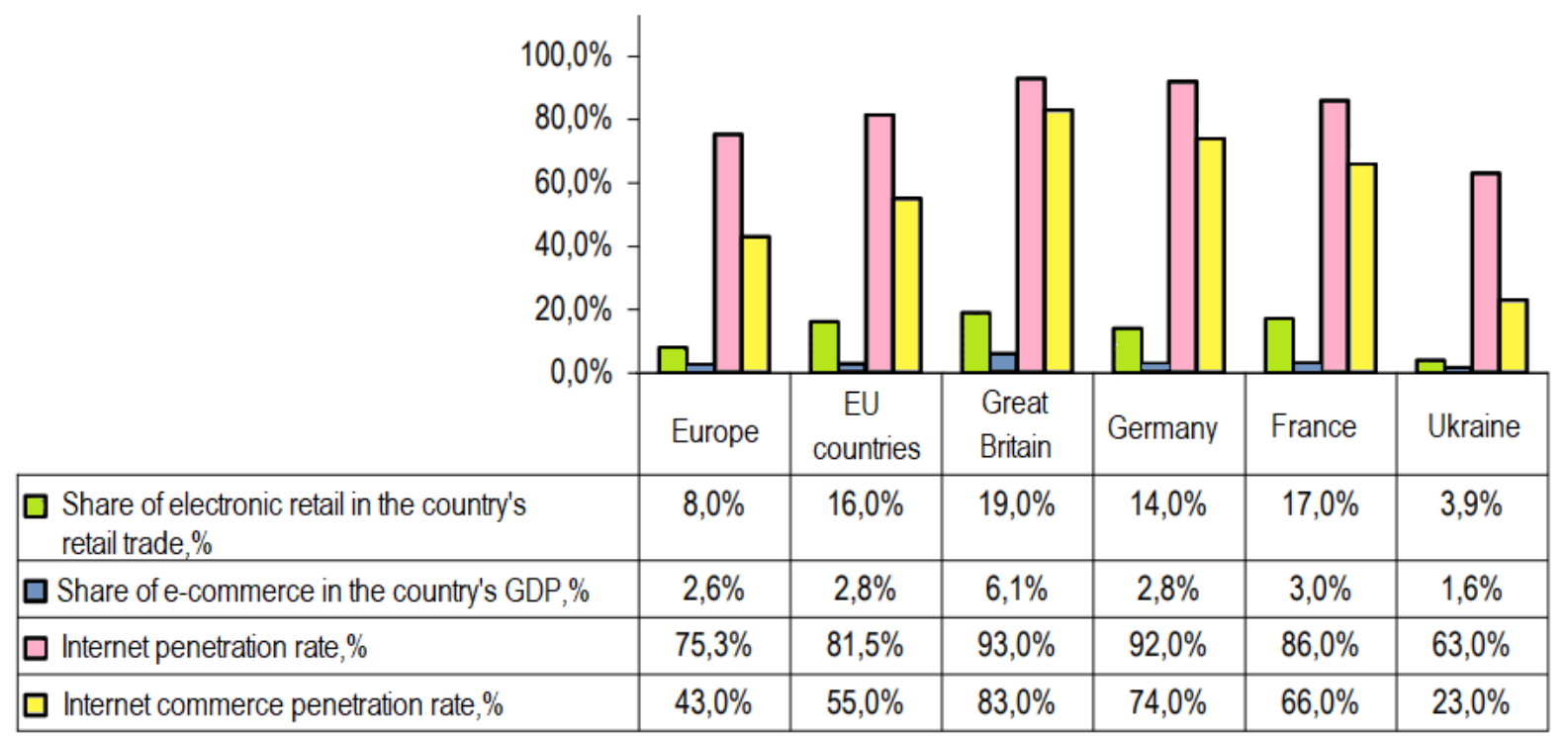

Fig. 3. The share of e-commerce in retailing and GDP in 2018 compared to Internet penetration rates

Table. 1. Dynamics of indicators of development of electronic commerce of Ukraine

\begin{tabular}{|l|c|c|c|c|c|c|}
\hline \multicolumn{1}{|c|}{ Indicator } & $\mathbf{2 0 1 3}$ & $\mathbf{2 0 1 4}$ & $\mathbf{2 0 1 5}$ & $\mathbf{2 0 1 6}$ & $\mathbf{2 0 1 7}$ & $\begin{array}{c}\mathbf{2 0 1 8} \\
\text { (forecast) }\end{array}$ \\
\hline $\begin{array}{l}\text { Volume of retail trade in Ukraine, bln. } \\
\text { UAH }\end{array}$ & 888,5 & 901 & 1031,7 & 1159,3 & 1228,8 & 1327,3 \\
\hline $\begin{array}{l}\text { Volume of retail trade in Ukraine, } \\
\text { bln.USD }\end{array}$ & 111,2 & 76,0 & 47,1 & 45,1 & 43,5 & 41,7 \\
\hline $\begin{array}{l}\text { Volume of retail trade in Ukraine, billion } \\
\text { euro }\end{array}$ & 83,7 & 57,4 & 42.6 & 41,0 & 42,3 & 42,5 \\
\hline $\begin{array}{l}\text { Volume of Internet commerce in Ukraine, } \\
\text { bln. UAH }\end{array}$ & 7,4 & 12,3 & 25,5 & 38,3 & 48 & 47 \\
\hline $\begin{array}{l}\text { Volume of Internet commerce in Ukraine, } \\
\text { bln. USD }\end{array}$ & 0,88 & 1,04 & 1,17 & 1,50 & 1,70 & 1,63 \\
\hline $\begin{array}{l}\text { Volume of Internet commerce in Ukraine, } \\
\text { bln. euro }\end{array}$ & 0,66 & 0,76 & 1,06 & 1,43 & 1,65 & 1,64 \\
\hline $\begin{array}{l}\text { annual growth index of retail trade in } \\
\text { hryvnia equivalents }\end{array}$ & $9,4 \%$ & $1,5 \%$ & $14,4 \%$ & $12,7 \%$ & $6,0 \%$ & $8,0 \%$ \\
\hline $\begin{array}{l}\text { Annual index of growth of retail trade in } \\
\text { dollar equivalent }\end{array}$ & $11,5 \%$ & $-31,1 \%$ & $-36,3 \%$ & $-4,3 \%$ & $-4,1 \%$ & $-4,2 \%$ \\
\hline $\begin{array}{l}\text { annual growth rate of retail trade in euro } \\
\text { equivalent }\end{array}$ & $5,7 \%$ & $31,2 \%$ & $-36,2 \%$ & $100,4 \%$ & $3,2 \%$ & $3,5 \%$ \\
\hline $\begin{array}{l}\text { annual growth rate of Internet commerce } \\
\text { in hryvnia equivalents }\end{array}$ & $53,7 \%$ & $72,5 \%$ & $72,5 \%$ & $12,4 \%$ & $25,0 \%$ & $22 \%$ \\
\hline $\begin{array}{l}\text { annual growth rate of Internet commerce } \\
\text { in dollar equivalent }\end{array}$ & $52,9 \%$ & $18,3 \%$ & $18,3 \%$ & $13,2 \%$ & $13,01 \%$ & $11,4 \%$ \\
\hline $\begin{array}{l}\text { annual growth rate of Internet commerce } \\
\text { in euro equivalent }\end{array}$ & $48,0 \%$ & $18,8 \%$ & $18,1 \%$ & $34,9 \%$ & $22,3 \%$ & $24,5 \%$ \\
\hline e-commerce penetration in Ukraine & $0,9 \%$ & $1,5 \%$ & $1,4 \%$ & $2,5 \%$ & 3,9 & $3,8 \%$ \\
\hline
\end{tabular}

However, the successful implementation of business on the Internet implies a transitional stage of its implementation, associated with the use of new electronic tools at enterprises, new methods and principles of work, improvement of the organizational structure and management system, optimization of business processes of the enterprise, with constant updating of knowledge and skills of 
its employees the like. Effective enterprise management becomes a key factor in increasing its competitiveness and requires the use of modern methods and tools adapted to work in the information society. The most significant factor in the management and development of a modern enterprise is recognized as dynamic changes in the external environment, whose influence on management efficiency is determined by expanding the boundaries of the enterprise's activities, complicating relations with customers and partners, and increasing the available information. As a result, the company grows the number of management decisions and shortens the time of their adoption, which causes the need to revise the methods, principles, tools of enterprise management in the direction of increasing the degree of its informatization. One of the advantages of developing e-business in an enterprise is the possibility of its transition to a new dual technology of value formation, which, unlike that developed by Michael Porter, consists of analyzing and controlling costs both in the traditional sense and depending on the extent of the information space covered by the enterprise and its use of information technology and systems in various parts of the value chain.

On the basis of generalization of foreign and domestic experience in electronic activity, its evolution identified stages of transition to electronic business of domestic enterprises (Table 2).

Table 2. Characteristics of the stages of development of e-business in the enterprise

\begin{tabular}{|c|l|l|}
\hline $\begin{array}{c}\text { Stages of } \\
\text { e-business } \\
\text { development }\end{array}$ & \multicolumn{1}{|c|}{ Characteristics of the stage } & \multicolumn{1}{|c|}{ Key actions } \\
\hline $\begin{array}{c}\text { General } \\
\text { informatization }\end{array}$ & $\begin{array}{l}\text { Formation of a strategic plan for } \\
\text { e-business, search for potential partners } \\
\text { and information about the infrastructure } \\
\text { of the Internet environment. }\end{array}$ & $\begin{array}{l}\text { - formation of IT infrastructure; } \\
\text { - informatization of activity; } \\
\text { - introduction of electronic document } \\
\text { flow }\end{array}$ \\
\hline $\begin{array}{c}\text { Representation } \\
\text { on the Internet }\end{array}$ & $\begin{array}{l}\text { Update of the company's website, } \\
\text { marketing experiments on the Internet }\end{array}$ & $\begin{array}{l}\text { - stimulating the use of the Internet, } \\
\text { - integration of internal information } \\
\text { resources of the enterprise }\end{array}$ \\
\hline $\begin{array}{c}\text { Creating } \\
\text { e-business } \\
\text { platform }\end{array}$ & $\begin{array}{l}\text { Implementation of specialized } \\
\text { information and computer technologies, } \\
\text { payment and other systems; } \\
\text { organization of personnel training; } \\
\text { information security system providing }\end{array}$ & $\begin{array}{l}\text { - creation of centers of data exchange } \\
\text { and networks of the enterprise; } \\
\text { - development of general IT } \\
\text { infrastructure; } \\
\text { - introduction of international regulations }\end{array}$ \\
\hline $\begin{array}{c}\text { Introduction of } \\
\text { e-commerce }\end{array}$ & $\begin{array}{l}\text { Implementation of e-commerce, } \\
\text { implementation of business projects } \\
\text { (innovative, industrial) on the basis of } \\
\text { e-business platform; } \\
\text { Internet providing service to customers }\end{array}$ & $\begin{array}{l}\text { - stimulation of interaction between } \\
\text { enterprises, partners and clients; } \\
\text { - providing efficient electronic services }\end{array}$ \\
\hline $\begin{array}{c}\text { Network } \\
\text { partnership }\end{array}$ & $\begin{array}{l}\text { Creation of corporate portals, } \\
\text { establishment of profitable partnerships } \\
\text { with clients, Internet partners }\end{array}$ & $\begin{array}{l}\text { - Integration of business and electronic } \\
\text { services; } \\
\text { - increase in the volume of electronic } \\
\text { services engagement and synergy. }\end{array}$ \\
\hline
\end{tabular}

The introduction of e-business involves the structuring and systematization of relevant processes in the enterprise, the success of which is ensured by the timely adaptation of management activities in a dynamic information environment enhancing the active management of the enterprise and the transformation of the management system, its constituent elements and relations between them, are undergoing transformations on an ongoing basis (Table 3 ). 
Table 3. Transformation of the components of the enterprise management system in e-business

\begin{tabular}{|l|l|}
\hline \multicolumn{1}{|c|}{ Elements Management System } & \multicolumn{1}{c|}{ Transformation } \\
\hline $\begin{array}{l}\text { Methodology of management } \\
\text { (laws, principles, methods, } \\
\text { functions, management technology) }\end{array}$ & $\begin{array}{l}\text { - combination of the principles of strategic management and network } \\
\text { management (by K. Kelly) } \\
\text { - expansion and differentiation of management functions in connection } \\
\text { with the diversification, virtualization and globalization of production; } \\
\text { - reorientation of strategic priorities with an emphasis on flexibility, } \\
\text { strengthening of program-targeted management, reorganization of } \\
\text { divisions and their interaction, strengthening integration. }\end{array}$ \\
\hline $\begin{array}{l}\text { Process of management } \\
\text { (communication system, } \\
\text { development and implementation } \\
\text { of managerial decisions, } \\
\text { information provision) }\end{array}$ & $\begin{array}{l}\text { - automation of management processes (planning, organization and } \\
\text { control) for pre-allocated centers of responsibility; } \\
\text { - provision of organizational, informational, financial-economic, social } \\
\text { and communication management mechanism; } \\
\text { - focusing on the management of intangible assets. }\end{array}$ \\
\hline $\begin{array}{l}\text { Management structure (functional } \\
\text { structures, information flows, } \\
\text { behavioral system, personnel } \\
\text { training) }\end{array}$ & $\begin{array}{l}\text { - the transition to a flexible, horizontal organizational structure through } \\
\text { a network of labor organization; } \\
\text { - reorganization of divisions, creation of strategic management } \\
\text { departments and development of e-business; } \\
\text { - formation of an effective system of motivation and training of the } \\
\text { personnel. }\end{array}$ \\
\hline $\begin{array}{l}\text { Technology and management } \\
\text { technology (communication } \\
\text { networks, document management } \\
\text { systems, communication systems) }\end{array}$ & $\begin{array}{l}\text { - creation of a common information space for enterprise management } \\
\text { based on an integrated integrated information system, with internal and } \\
\text { external communications and connections of the enterprise. }\end{array}$ \\
\hline
\end{tabular}

Conclusions. Thus, the transformation of the management system at the enterprise leads to a new higher level of development related to meeting the needs of consumers that arise in the information environment and which the enterprise must comply with (flexibility, prompt delivery of information, 24-hour on-line presence on the Internet, etc.). The article states that the intensive development of e-business technologies requires an appropriate timely transformation of the services and departments of the enterprise to e-business. Under such conditions, the integrative role of management in the formation of an innovative way of enterprise development increases.

\section{REFERENCES}

1. European B2C E-commerce Report 2016. [Electronic resource]. - Access mode: https://www.ecommerceeurope.eu/app/uploads/2016/07/European-B2C-E-commerce-Report-2016-LightVersion-FINAL.pdf.

2. Hlinenko L.K., Dainovskyi Yu.A. Stan i perspektyvy rozvytku elektronnoi torhivli Ukrainy // Marketynh i menedzhment innovatsii. - 2018. - № 1. - [Electronic resource]. - Access mode: http://mmi.fem.sumdu.edu.ua/sites/default/files/mmi2018_1_83_102.pdf

3. Horbenko A. E-trade in Ukraine: serfynh trendov. [Electronic resource]. - Access mode: http://logist.fm/publications/e-trade-ukraine-serfing-trendov.

4. Pronyknennia Internet $\mathrm{v}$ Ukraini. [Electronic resource]. - Access mode: http://ukraine.momrsf.org/fileadmin/Editorial/Ukraine/Documents/D-33.pdf.

5. Pachkovskyy Y. The Young Consumer in the Ukrainian e-Commerce Market / Y. Pachkovskyy, A. Maksymenko // Handel wewnętrzny. - 2016. - № 4 (363). - P. 202 - 216

6. Eurostat data: Share of enterprises' turnover on e-commerce. [Electronic resource]. - Access mode: http://ec.europa.eu/eurostat/tgm/table.do?tab= table\&init=1\&language=en\&pcode=tin00110\&plugin=1.

7. Melnychuk O. Rozvytok elektronnoi komertsii u strukturi informatsiinoi ekonomiky Ukrainy / O. Melnychuk // Visnyk Kyivskoho natsionalnoho universytetu imeni Tarasa Shevchenka. Серія Економіка. - 2014. - № 8(161). - P. 93-97. 